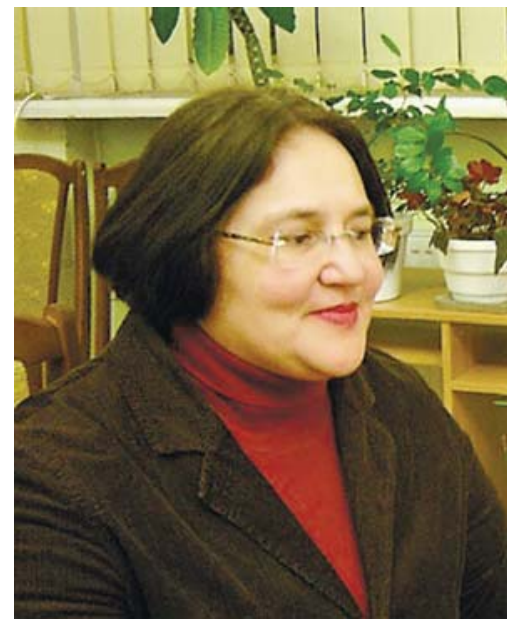

лОБУзІнА

Катерина Вілентіївна доктор наук із соціальних комунікацій, директор Інституту інформаційних технологій Національної бібліотеки України ім. В.I. Вернадського

\section{РЕПОЗИТАРІЙ НАУКОВИХ ТЕКСТІВ НАН УКРАЇНИ В НАЦІОНАЛЬНІЙ БІБЛІОТЕЦІ УКРАЇНИ іМ. В.І. ВЕРНАДСЬКОГО: СТАН І ПЕРСПЕКТИВИ РОЗВИТКУ}

\author{
За матеріалами доповіді на засіданні \\ Президії НАН України 29 вересня 2021 року
}

У доповіді акцентовано увагу на змінах і новаціях у цифровій науковій комунікацї, які обов'язково має опанувати сучасний науковещь. Важливий інструментарій управління цифровою науковою інформацією надають репозитарії наукових установ. Запропоновано створити консолідований репозитарій наукових текстів НАН України на базі цифрової платформи бібліотечного порталу LibNAS UA в Начіональній бібліотеці України ім. В.І. Вернадсъкого на корпоративних засадах з науково-дослідними установами Академіі. Презентовано структуру та функціональні можливості LibNAS UA. Зазначено, що реалізачія проєкту репозитарію НАН Украйни сприятиме формуванню позитивному іміджу наукових установ $i$ вчених Академії в наукових цифрових комунікаціях.

Ключові слова: наукова інформація, наукові цифрові комунікації, електронна дослідницька інфраструктура, бібліотечні портали знань, репозитарій НАН України.

Зміни у цифровій науковій комунікації. Сучасна цифрова наукова комунікація розвивається в руслі глобальної цифровізації всіх суспільних процесів. За останнє десятиліття відбулися незворотні зміни у цифровій науковій комунікації, які привели до циркулювання величезних обсягів наукових даних. Відповідно, сьогодні вченим необхідні електронна дослідницька інфраструктура та сервіси управління дослідницькими даними, аналогічні тим, які надавалися бібліотеками та системами наукової інформації у традиційному паперовому форматі. Дослідники відзначають 101 ланку модерної цифрової наукової комунікації, які обов’язково має опанувати сучасний науковець і які супроводжують всі стадії наукового процесу: фінансування, дослідження, аналіз, написання, публікація, застосування, оцінювання тощо. Наявність досконалого цифрового портфо- 
ліо наукових установ та вчених сьогодні стала обов'язковим атрибутом дослідницької діяльності, який значно впливає на наукову репутацію. Дані про дослідницьку діяльність та процеси мають нині стратегічну актуальність і життєво важливе значення для наукової комунікації та управління дослідженнями. Упорядкування значних масивів наукових даних трудомістка і часозатратна робота, але в перспективі вона дає дослідникам значні переваги в процесі пошуку джерел наукової інформації, партнерів, звітування та оцінки результатів наукової діяльності. Важливий інструментарій управління цифровою науковою інформацією надають репозитарії наукових установ [1].

Відкритий доступ до наукової інформаціі. Сучасне розуміння електронної дослідницької інфраструктури тісно пов'язане з поняттям відкритої науки (Open Science). Це сукупність дій, спрямованих на те, щоб зробити наукові процеси більш прозорими, а наукові результати - більш доступними. У 2018 р. Свропейська комісія та Європейська дослідницька рада ініціювали перехід з 2021 р. до відкритого доступу до наукових публікацій, які публічно фінансуються Європейською дослідницькою радою.

Було розроблено Plan $S$, згідно з яким недоцільно підтримувати передплатну бізнес-модель для наукових публікацій у цифровому світі, в якому відкритий доступ надає рівні умови і максимізує вплив, видимість та ефективність усього наукового процесу. Для реалізації цих ініціатив було створено загальноєвропейський науковий репозитарій OpenAIRE, який консолідує наукові метадані та надає платформу для розміщення повних текстів наукових публікацій у відкритому доступі [2].

У межах ініціатив відкритого доступу було також створено національні репозитарії, які підтримуються науковими бібліотеками національних академій наук Китаю та Індії. Обов'язковим атрибутом таких ресурсів є англомовний інтерфейс.

Тут слід зауважити, що обов'язковий відкритий доступ до наукових публікацій викликав хвилю критики з боку представників наукових установ і видавництв, які вважають його несправедливим через серйозні комерційні ризики. Проте ініціативу відкритого доступу підтримано в усьому світі для наукових творів, які виконувалися за державний кошт i доступ до яких не обмежений фінансовими зобов’язаннями. Зважаючи на те, що в сучасних наукових установах застосовуються різні видавничі моделі, інституційні репозитарії перейшли до поміркованих варіантів доступу до наукової інформації, таких як:

• відкритий доступ до повного тексту видання;

- ембарго на публікацію повного тексту від 0,5 до 2 років;

- депозитарне зберігання з анотованим бібліографічним описом без доступу до повного тексту.

Саме за цими принципами ми пропонуємо організувати взаємодію з правовласниками наукових творів у репозитарії НАН України.

Ситуація в Україні. Останнім часом процеси створення цифрової дослідницької інфраструктури активізувалися також і в Україні. Міністерство освіти та науки України видало низку розпорядчих документів і постанов щодо організації інституційних репозитаріїв та затвердило Положення про Національний репозитарій академічних текстів (НРАТ). Підсумки роботи комісії МОН України зі створення НРАТ у 2017 р. показали, що переважна більшість провідних закладів вищої освіти створили і підтримують роботу власних інституційних репозитаріїв. У 2011 р. для Національної академії педагогічних наук Інститут інформаційних технологій і засобів навчання НАПН України створив за принципами репозитарію «Електронну бібліотеку НАПН України» (lib.iitta.gov.ua). У 2019 р. запрацював «Національний репозитарій академічних текстів (НРАТ)», створений Українським інститутом науково-технічної експертизи та інформаціï, який неповно представляє ресурси науки, містить переважно повні тексти авторефератів дисертацій, дисертації та науково-технічні звіти (nrat.ukrintei.ua) [3].

Стан справ у НАН України. Серед репозитаріїв науково-дослідних установ НАН України 
комісією МОН було відзначено лише репозитарій наукової періодики «Електронна наукова бібліотека періодичних видань НАН України», створений у 2012 р. та підтримуваний Інститутом програмних систем НАН України (dspace.nbuv.gov.ua). Цей репозитарій вирішує важливе завдання з представлення наукової періодики Академії, але не має повноти подання інформації про видавничу й публікаційну діяльність НАН України в цілому, а саме:

- містить публікації науковців 3 інших установ;

- не містить інформації про всі публікації науковців НАН України, зокрема про монографічні видання та статті в неакадемічних журналах;

- не надає можливості виокремити публікації за персональною та інституційною належністю;

- не має англомовного інтерфейсу.

Об'єктивна необхідність створення репозитарію НАН України як потужного ресурсу відкритої науки очевидна, але реалізація цього завдання пов'язана з низкою проблем і недоліків, які потрібно усунути:

- розпорошеність інформації про результати наукової діяльності;

- відсутність консолідованого представлення бібліографії всіх наукових публікацій НАН України;

- некоректність представлення метаданих наукових видань НАН України (зокрема, англійською мовою) у міжнародних системах наукової інформації;

- відсутність повноцінних наукових профілів установ та науковців НАН України (зокрема, англійською мовою);

- складність отримання стандартизованої бібліометричної та наукометричної інформації.

Це перешкоджає забезпеченню відкритого доступу та депозитарного зберігання результатів наукової діяльності в електронному вигляді.

Передумови створення репозитарію НАН України в НБУВ. Під час обговорення стану справ з інституційними репозитаріями в комісіях МОН України та на наукових конферен- ціях неодноразово поставало питання щодо наявності репозитарію НАН України. Очевидним є той факт, що відсутність консолідованого представлення результатів діяльності наукових установ НАН України у відкритому доступі знижує конкурентоспроможність науковців Академії навіть за умови об'єктивних наукових досягнень світового рівня, високих наукометричних показників та провідних позицій у вітчизняному науково-інформаційному просторі.

Створення консолідованого ресурсу відкритої науки в багатьох державах покладено на наукові бібліотеки, які володіють відповідними технологіями і мають фахівців у галузі управління даними. Упорядкування наукової інформації поза експертним бібліотечним середовищем пов'язане зі значними негативними наслідками, небажаними для світової наукової спільноти, а саме:

- недоступність, неповнота або неякісність даних;

- комерціалізація та перехід у приватну власність наукової інформації;

- загальнодоступні платформи відкритого доступу та стихійно створені сервіси обміну самоархівованими науковими публікаціями в багатьох випадках містять неякісну та недостовірну інформацію;

- методично і технологічно неузгоджений характер різноманітних наукових цифрових проєктів на етапі інтеграції наукових даних виявляє їх принципову несумісність.

У напрямі підтримки ініціатив відкритого доступу до результатів наукових досліджень в Україні в НБУВ за період 2011-2021 рр. напрацьовано значний досвід формування корпоративних електронних ресурсів. 3 корпоративним сервером НБУВ з 2016 р. вже співпрацюють 22 бібліотеки науково-дослідних установ НАН України для формування електронного каталогу. $€$ також досвід створення електронних архівів наукових публікацій: «Наукова періодика України» (співпраця з понад 1,5 тис. наукових видавництв) (з 2014 р.), «Електронна бібліотека Інституту історії України» (з 2016 р.) та «Репозитарій НБУВ -

ISSN 1027-3239. Visn. Nac. Acad. Nauk Ukr. 2021. (11) 
EverLib» (з 2018 р.), сайти наукових журналів (з 2017 р.), два з яких - «Рукописна та книжкова спадщина України» та «Український історичний журнал» індексуються Scopus i Web of Science. Розроблено та апробовано в тестовому режимі низку інструментів для передавання та отримання метаданих для різних сучасних інформаційних систем.

За останнє десятиліття в НБУВ пройшли спеціальну підготовку бібліотечні фахівці 3 управління цифровими науковими даними (за кордоном таких спеціалістів називають стюардами даних або цифровими бібліотекарями).

Наявні в НБУВ електронні бібліографічні ресурси, створені на основі вітчизняних та міжнародних стандартів, дають можливість значно оптимізувати роботу з бібліографічною інформацією. Поряд з повними текстами статей в електронних ресурсах НБУВ є повні тексти приблизно 1 тис. монографічних видань Академії. В останні 5 років розпочався стихійний процес створення бази даних монографічних видань: сотні авторів, співробітників НАН України та інших інституцій, звернулися з проханням розмістити їхні монографії у відкритому доступі на порталі НБУВ.

Сьогодні НБУВ є найбільшим в Україні інтегратором наукових інформаційних ресурсів, а тому за рейтингом видач у пошукових запитах Google розміщені в НБУВ публікації опиняються в перших рядках відповіді браузера. Отже, ресурси, розміщені на цифровій платформі НБУВ, автоматично стають доступнішими для інтернет-користувачів і достойно представляють українську академічну науку.

Репозитарій наукових текстів НАН Украіни у складі бібліотечного порталу LibNAS UA. Для ліквідації лакуни в інформаційному просторі цифрових наукових комунікацій НБУВ має можливість створити на корпоративних засадах з науково-дослідними установами Академії «Репозитарій наукових текстів НАН України» 3 розширеними функціями управління інформацією на базі цифрової платформи «Бібліотечний портал НАН України - LibNAS UA» (Library Portal of National Academy of Sciences of Ukraine). Попередні розробки показали, що цей портал доцільно розвивати саме у Національній бібліотеці України ім. B.I. Вернадського, оскільки вона зможе системно інтегрувати ресурси всієї Академії та організувати поповнення і управління ресурсом на постійній основі.

Цифрову платформу LibNAS UA для сумісності з іншими міжнародними системами управління науковою інформацією було розроблено на основі єдиного європейського формату наукової інформації CERIF (Common European Research Information Format), рекомендованого для країн ЄС. Формат містить такі основні елементи: інституційна інфраструктура (установи, персоналії) та дослідницький репозитарій (наукові тексти) [4].

Сайт бібліотечного порталу НАН України LibNAS UA доступний у тестовому режимі за інтернет-адресою libnas.nbuv.gov.ua [5]. Структура порталу LibNAS UA складається із взаємопов'язаних блоків, центральним з яких, відповідно до європейського стандарту, є блок «Науковці» (див. рис.).

Інституційна інфраструктура LibNAS UA (установи та науковці). Детальніше розглянемо інституційну інфраструктуру порталу.

Установи. На порталі LibNAS UA список установ подано відповідно до структури НАН України, є можливість пошуку установ за будь-якими фрагментами назви. Кожен запис про установу містить іï історичні назви від часу заснування українською мовою та їх англомовні аналоги. $\mathrm{C}$ можливість дізнатися про всіх очільників установи з часу іï заснування, переглянути наявні в НБУВ видання за всіма бібліографічними варіантами написання назви установи, наукові періодичні видання установи, перейти на сайт установи, подивитися міжнародні ідентифікатори (ISNI, WIAF, WorldCAT, ROR, GRID, WikiData), наукометричні профілі установи (Scopus, Web of Science, Publons, Google Scholar) та поточні наукометричні показники (кількість публікацій і цитувань, індекс Гірша). У перспективі планується, що цей блок буде пов'язаний з науковцями, публікаціями, періодикою та журналами. 


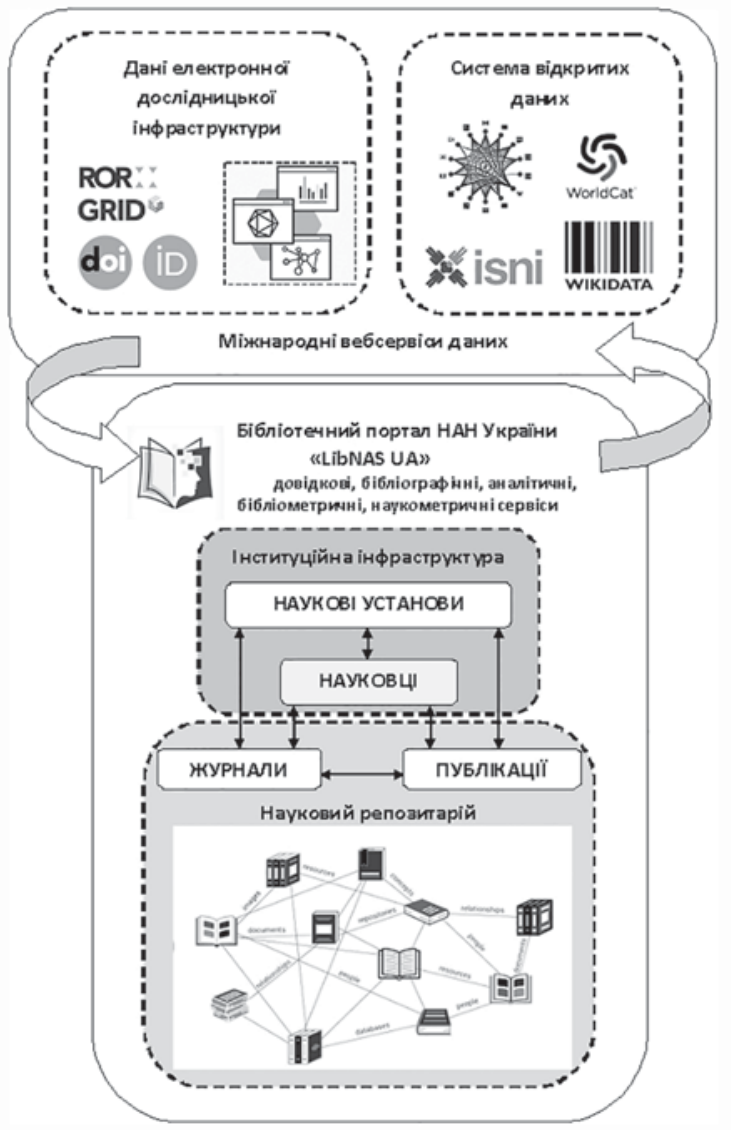

Структура бібліотечного порталу НАН України LibNAS UA

Науковці. Складено алфавітний список науковців НАН України з можливістю пошуку за будь-яким фрагментом прізвища. Кожен запис містить стислу інформацію про дати життя, освіту, наукові ступені та вчені звання, професійну діяльність, пов’язану насамперед з установами НАН України, викладацьку діяльність, наявні в НБУВ праці вченого та літературу про нього за всіма бібліографічними варіантами написання імені вченого, нагороди, науково-видавничу діяльність (участь у редколегіях наукової періодики), міжнародні ідентифікатори (ISNI, WIAF, WorldCAT, ORCID, WikiData). Є можливість переглянути наукометричні профілі вченого (Scopus, Web of Science, Publons, Google Scholar) та поточні наукометричні показники (кількість публікацій і цитувань, індекс Гірша). У перспективі цей блок планується пов’язати з установами, публікаціями, періодикою.

Репозитарій НАН України (публікації та періодика). Проєкт «Репозитарій НАН України» передбачає подання інформації у двох взаємопов’язаних блоках: «Публікації» i «Журнали».

Публікаціі. Репозитарій НАН України є консолідованим і структурованим зібранням наукових текстів - авторських творів працівника(ів) наукових установ НАН України, що пройшли наукове рецензування і затверджені до публікації або інших форм розповсюдження наукового тексту, що має науковий, науковотехнічний або навчальний характер, у формі дисертації, автореферату, різних видів наукових видань, зокрема монографії, наукової статті, наукового каталогу та покажчика, науководовідкового та енциклопедичного видання, підручника, збірника матеріалів конференції, звіту у сфері наукової і науково-технічної діяльності тощо.

Метадані статей подаватимуться обов'язково українською та англійською мовами, буде зазначено DOI та УДК, для журнальних статей - індексування наукометричними базами даних Scopus та Web of Science, квартиль, категорія ДАК України.

У перспективі цей блок планується пов'язати з установами (видавцями та постачальниками інформації), науковцями (авторами текстів).

Журнали. У цьому блоці передбачається консолідувати інформацію про всі періодичні видання НАН України (історичні та сучасні); видання, в яких публікуються співробітники НАН України; видання НАН України, які входять до наукометричних баз даних Scopus та Web of Science; фахові видання за категоріями ДАК України.

У перспективі цей блок планується пов'язати з публікаціями (статтями у періодичних виданнях), установами (видавцями), науковцями (авторами текстів та членами редколегій).

Такий портал може ефективно вирішувати низку завдань:

ISSN 1027-3239. Visn. Nac. Acad. Nauk Ukr. 2021. (11) 
- приведення наукових метаданих у відповідність до сучасних міжнародних стандартів;

- забезпечення відкритого доступу до результатів наукової діяльності;

- представлення систематизованих результатів наукової діяльності за науковими напрямами та видами наукових публікацій;

- можливість інтеграції до національної, європейської та світової дослідницької інфраструктури;

- збереження наукових досягнень учених;

• удосконалення обліку й моніторингу публікаційної та видавничої активності;

- оптимізація процесу підготовки звітної та атестаційної документації;

- проведення аналітичних, бібліометричних, наукометричних досліджень.

Користувацький інтерфейс репозитарію НАН України передбачає:

- двомовне подання інформації про кожен науковий текст (українською та англійською мовами);

- стале зручне посилання на сторінку і повний текст публікації;

• розміщення обкладинки книги або журналу;

- надання інформації про постачальника даних (наукову установу);

- посилання на персональні сторінки авторів;

- коректне бібліографічне посилання (англійською та українською мовами) в міжнародному форматі пристатейної бібліографії (references).

Наявність англомовного інтерфейсу дасть можливість проіндексувати метадані наукових публікацій Академії міжнародними системами наукової інформації, що забезпечить їх більшу відкритість для міжнародної аудиторії. Ці англомовні сторінки та стислі посилання можна буде також використовувати для реєстрації DOI на рівні монографічних видань.

Відкритий доступ до повних текстів публікацій забезпечить їх повнотекстове індексування пошуковими системами, підвищить наукометричні показники їх цитування. Так, досвід індексування електронного архіву «Наукова періодика України» системою Google Scholar y 2014 р. показав, що коректне переда- вання метаданих та автоматичний аналіз пристатейної бібліографії повних текстів статей забезпечили протягом року зростання кількості цитувань публікацій українських науковців у $3-4$ рази.

Наукометричні показники як складова бібліотечного порталу LibNAS UA. Додатково до консолідації та забезпечення збереження бібліографічної і повнотекстової інформації, розпорошеної наразі по різних сайтах установ НАН України, функціонал LibNAS UA забезпечує консолідацію наукометричних показників Академії. Вивчення світового досвіду свідчить про те, що створення наукометричних інструментів на базі обмеженої вибірки публікацій учених Академії є абсолютно недоцільним, оскільки не відображатиме інтегрованість наукових досягнень до світового наукового простору. Тому інструментарій LibNAS UA забезпечує консолідоване подання наукометричних показників Академії в найпотужніших базах даних наукової інформації - Scopus, Web of Science, Google Scholar, Publons.

Так, на виконання постанови Президії НАН України від 19 червня 2021 р. «Щодо удосконалення організації обліку та моніторингу публікаційної та видавничої активності НАН України» співробітники НБУВ провели значну роботу з уніфікації інформації в базах даних бібліометричних систем, у яких спостерігався великий різнобій даних, що перешкоджало підготовці коректної статистики. Вже опрацьовано та представлено на порталі LibNAS UA взаємопов'язану інформацію щодо:

- 184 наукових установ НАН України (зі зведеними різночитаннями назв українською і англійською мовами);

- 1426 вчених НАН України: академіків, членів-кореспондентів, очільників установ (зі зведеними різночитаннями імен українською і англійською мовами);

- 850 наукометричних профілів (261 установа та 589 науковців) в системах Scopus, Web of Science, Google Scholar, Publons.

Крім того, налагоджено щоквартальний моніторинг наукометричних показників НАН 
України, підготовлено методичні рекомендації для створення та управління науковими профілями установ і науковців у різних системах наукової інформації (Scopus, Web of Science, Google Scholar, ORCID, Publons).

Доступ до історичної спадщини НАН України у цифровому форматі. Репозитарій НАН України можна використовувати для архівування та надання доступу до історичної наукової спадщини НАН України від часу їі заснування. Вже оцифровано та описано 620 видань Академії за період 1918-1991 рр.

У межах проєкту бібліотечного порталу НАН України можуть бути створені цифрові колекції видатних науковців Академії. Підгрунтя для низки меморіальних колекцій вже закладено і охоплює такі персоналії, як Володимир Іванович Вернадський, Агатангел Юхимович Кримський, Борис Євгенович Патон. Планується продовжити оцифрування i peтрокаталогізацію наукового доробку видатних учених Академії починаючи з 12 перших академіків УАН та президентів Академії.

Перспективи розвитку репозитарію НАН України. Репозитарій має бути власністю НАН України, а його інституційні складові формуватися з дотриманням авторського права установ та вчених Академії. Установи - учасники формування репозитарію НАН України зможуть у будь-який момент отримати резервну копію переданих до НБУВ даних. Розміщення інформації в репозитарії не виключає паралельне розміщення її на сайті установи та інших інтернет-ресурсах.
LibNAS UA передбачає сумісність з науковими профілями установ та науковців на офіційному порталі НАН України; Національним репозитарієм академічних текстів, що створюється МОН України; проєктом Європейської хмари відкритої науки.

Підтримка загальноакадемічного репозитарію є корпоративним завданням усіх науководослідних установ НАН України, яке вже давно назріло. Узгоджені технології та уніфіковані підходи, які розроблялися в НБУВ, мають пройти обговорення в найближчій перспективі, їх буде відображено в документах «Положення про Репозитарій НАН України у складі LibNAS UA» та «Регламент роботи Репозитарію НАН України».

Ідея створення LibNAS UA та репозитарію НАН України спрямована на формування, нарощування та підтримку потужного ресурсу нової якості як системного джерела багатоаспектної інформації щодо досягнень та розвитку української академічної науки в її динаміці та різних напрямах, яке зможе надавати всебічну, достовірну та повноцінну інформацію для вчених та забезпечувати нові можливості аналізу й управління інформацією.

Реалізація корпоративного проєкту «Репозитарій НАН України» безумовно сприятиме створенню позитивного іміджу наукових установ і вчених Академії в наукових цифрових комунікаціях і дасть їм змогу посісти достойне місце у світових та загальнодержавних наукових ресурсах, на яке вони цілком заслуговують. Дякую за увагу! 


\section{REFERENCES}

\section{[СПИСОК ЛІТЕРАТУРИ]}

1. Lobuzina K., Harahulia S., Konoval L., Lobuzin I. Digital society library in providing system support to science research. Library Science. Record Studies. Informology. 2020. (4): 5-12. DOI: https://doi.org/10.32461/24099805.4.2020.227040.

[Лобузіна К., Гарагуля С., Коновал Л., Лобузін І. Бібліотека цифрового суспільства в забезпеченні системної підтримки наукових досліджень. Бібліотекознавство. Документознавство. Інформологія. 2020. №. 4. С. 5-12].

2. OpenAIRE Guidelines for CRIS Managers. 2020. https://openaire-guidelines-for-cris-managers.readthedocs.io/_ downloads/en/latest/pdf/

3. National repository of academic texts: open access to scientific information. Kyiv: UkrINTEI, 2017. http://essuir.sumdu.edu.ua/handle/123456789/66379 (in Ukrainan).

[Наиіональний репозитарій академічних текстів: відкритий доступ до наукової інформаиіӥ: монографія. Київ: УкрIHTEI, 2017.]

4. Common European Research Information Format (CERIF): Main features. https://eurocris.org/services/main-features-cerif

5. LibNAS UA - Library Portal of National Academy of Sciences of Ukraine. http://libnas.nbuv.gov.ua/

\section{Katherina V. Lobuzina}

Vernadsky National Library of Ukraine

ORCID: https://orcid.org/0000-0003-3371-4029

\section{REPOSITORY OF SCIENTIFIC TEXTS OF THE NAS OF UKRAINE IN THE VERNADSKY NATIONAL LIBRARY OF UKRAINE: STATE AND PROSPECTS OF DEVELOPMENT}

According to the materials of report at the meeting of the Presidium of NAS of Ukraine, September 29, 2021

The report focuses on the changes in digital scientific communication that a modern scientist must master. An important tool for managing digital scientific information is provided by repositories of scientific institutions. It is proposed to create a consolidated repository of scientific texts of the NAS of Ukraine on the basis of the digital platform of the Library Portal "LibNAS UA" in the Vernadsky National Library of Ukraine on a corporate basis with research institutions of the Academy. The structure and functionality of "LibNAS UA" are presented. It is noted that the implementation of the project of Repository of the NASU will contribute to the positive image of scientific institutions and scientists of the NAS of Ukraine in scientific digital communications.

Keywords: research information, scientific digital communications, electronic research infrastructure, library portals of knowledge, repository of the NAS of Ukraine. 